\title{
Multi-walled Carbon Nanotubes Synthesis by Arc Discharge Method in a Glass Chamber
}

Arturo Tepale-Cortés, Hilda Moreno-Saavedra*, Celso Hernandez-Tenorio, Teresa Rojas-Ramírez, Javier Illescas

Tecnológico Nacional de México/ Instituto Tecnológico de Toluca, División de Estudios de Posgrado e Investigación. Av. Tecnológico s/n. Colonia Agrícola Bellavista, Metepec, Edo. De México, México, C.P. 52149 .

*Corresponding author: Hilda Moreno-Saavedra, email: hmorenos@toluca.tecnm.mx.

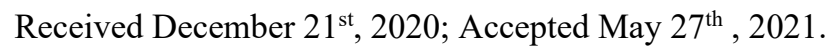

DOI: http://dx.doi.org/10.29356/jmcs.v65i4.1486

\begin{abstract}
In the present paper, carbon nanotubes (CNTs) were synthesized by arc discharge method by vaporizing graphite rods in the presence of $\mathrm{Ni}$ and a $\mathrm{Ni} / \mathrm{Y}$ mixture as catalysts for subsequent use in electrical energy storage and conversion devices. CNTs synthesis was carried out in a cylindrical glass reactor applying a controlled Argon flow of $1.43 \mathrm{~cm}^{3} / \mathrm{min}$ and a chamber pressure of $39 \mathrm{kPa}$. Carbon powder was collected from the reactor following chemical treatment with $\mathrm{HCl}$ solution at $1 \mathrm{M}$ to remove the metallic impurities. Morphology obtained by scanning electron microscopy (SEM) and transmission electron microscopy (TEM) showed multi-walled nanotubes (MWCNTs) with amorphous carbon particles attached to their surface. Fourier transform infrared (FT-IR) spectra presented bands at $\tilde{v} 1550$ and $1200 \mathrm{~cm}^{-1}$ corresponding to the $\mathrm{C}=\mathrm{C}$ bond characteristic to the CNTs skeleton; these bands were not present in pristine graphite. Electromagnetic absorbance was observed using ultraviolet-visible spectroscopy (UV-Vis) showing peaks at 204 and $256 \mathrm{~nm}$ related to $\mathrm{sp}^{2}$ hybridization characteristic for MWCNTs.
\end{abstract}

Keywords: CNT; arc discharge; catalyst; MWCNT; hybridization.

Resumen. En el presente trabajo se sintetizaron nanotubos de carbono (NTCs) por el método de descarga de arco mediante la vaporización de barras de grafito en presencia de $\mathrm{Ni}$ y una mezcla de $\mathrm{Ni} / \mathrm{Y}$ como catalizadores para su posterior uso en dispositivos de almacenamiento y conversión de energía eléctrica. La síntesis de NTCs se realizó en un reactor cilíndrico de vidrio aplicando un flujo controlado de Argón de $1.43 \mathrm{~cm} / 3$ min y una presión de cámara de $39 \mathrm{kPa}$. El polvo de carbón se recolectó del reactor y se trató químicamente con una solución de $\mathrm{HCl}$ a $1 \mathrm{M}$ para eliminar las impurezas metálicas. La morfología obtenida por microscopía electrónica de barrido (MEB) y microscopía electrónica de transmisión (MET) mostró nanotubos de paredes múltiples (NTCPMs) con partículas de carbón amorfo adheridas a su superficie. Los espectros de infrarrojo transformada de Fourier (FT-IR) mostraron bandas en $\tilde{v} 1550$ y $1200 \mathrm{~cm}^{-1}$ que corresponden al enlace $\mathrm{C}=\mathrm{C}$ característico de los NTCs; estas bandas no estuvieron presentes en el grafito prístino. La absorbancia electromagnética se observó mediante espectroscopia ultravioleta-visible (UV-Vis) mostrando picos a 204 y $256 \mathrm{~nm}$ relacionadas con la hibridación $\mathrm{sp}^{2}$ característica de los NTCPMs.

Palabras clave: NTC; descarga de arco; catalizadores; NTCPM; hibridación. 


\section{Introduction}

Carbon nanotubes (CNTs) are strong and ordered cylindrical structures with one or more concentric walls with interlayers distances from 0.34 to $0.39 \mathrm{~nm}$, diameters in nanometers, and lengths in micrometers $[1,2]$. The unique properties of CNTs like high surface area [3], electrical conductivity [4,5], thermal and chemical stability [5] have attracted great interest for potential applications as the development of energy storage [3,6] and conversion devices [7] such as supercapacitors [8], Organic Photovoltaic Cells (OPC) [9] and others. Conductive polymer and CNTs are capable of forming clusters due to the strong bonds [10]. CNTs and conductive polymers form composites [11] that increase photo-generated charge transport, obtaining high conversion efficiency, exhibiting higher light absorption and electrical power in OPCs [12].

The main methods used for CNTs synthesis are chemical vapor deposition (CVD), laser ablation, and arc discharge. CVD is a simple method that utilizes hydrocarbon gases as a carbon source and metal catalyst for nanotube growth at temperatures from 500 to $1000^{\circ} \mathrm{C}$. This method produces high purity CNTs at a large scale but with structural defects [13]. On the other hand, laser ablation and arc discharge methods employ solidstate carbon by vaporizing carbon at temperatures above thousands of degrees Celsius producing high-quality nanotube structures [2]. However, laser ablation is a method that is limited to laboratory scale [13]. The arc discharge is a simple and inexpensive physical method that produces high-quality carbon nanotubes at a large scale $[2,13]$. CNTs synthesis is carried out vaporizing graphite in an arc discharge, controlling temperature, pressure, voltage, and current. This arc discharge is produced between two graphite bars separated a few millimeters by applying voltages from 10 to $100 \mathrm{~V}$ and currents from 1 to $100 \mathrm{~A}$ [14-16]. Metallic catalysts such as transition metals $(\mathrm{Y}, \mathrm{Ni}, \mathrm{Co}, \mathrm{Fe})$, metallic oxides $\left(\mathrm{Y}_{2} \mathrm{O}_{3}, \mathrm{Al}_{2} \mathrm{O}_{3}\right)$, and metal mixtures $(\mathrm{Ni} / \mathrm{Y}, \mathrm{Ni} / \mathrm{Fe}$, $\mathrm{Fe} / \mathrm{Co}$ ) are used for the growth of CNTs [16-18].

CNTs synthesis produce samples significantly contaminated by amorphous carbon and metallic impurities [19-21]. These impurities interfere with the properties, characterization, and applications of CNTs [22]. Metal-doped CNTs are specially required in electronic devices and the electrocatalysis process. [23,24]. However, pure CNTs are needed in water purification technologies, optoelectronics, biosensors, fuel cells, electrode arrays, drug delivery, and others [25-27]. Therefore, acid treatment is necessary to eliminate metallic impurities [19-21]. $\mathrm{HCl}, \mathrm{HNO}_{3}$, and $\mathrm{H}_{2} \mathrm{SO}_{4}$ acids are commonly used to dissolve exposed metallic particles on CNTs [21]. Sharma et al. synthesized MWCNTs by the arc discharge method varying current in the range from 50 to 200 A [9]. On the other hand, Raniszewki et al. produced MWCNTs by electric arc method with metal catalysts observing that the carbon element flux changed significantly [28]. Roslan et al. obtained nanotubes through an arc discharge at a voltage of $12 \mathrm{~V}$, a current of $70 \mathrm{~A}$, and in the presence of magnetic fields obtaining straight MWCNTs [29]. Yermagambet et al. vaporized graphite by arc discharge method at a constant voltage of $50 \mathrm{~V}$ and currents of 120,150,170 and $200 \mathrm{~A}$ in an inert argon atmosphere obtaining CNTs with diameters from 58 to $370 \mathrm{~nm}[30]$.

In this paper, CNTs were synthesized by vaporizing graphite rods applying an arc discharge in the presence of powdered metallic Ni or Ni/Y mixture acting as catalysts. An average voltage and a peak current used during the arc discharge generation were $30 \mathrm{~V}$ and $95 \mathrm{~A}$. Hydrochloric acid $(\mathrm{HCl})$ was used to remove metallic residues from the obtained CNTs. An ultrasonic bath was used for 60 minutes to disperse the amorphous carbon clusters. CNTs were characterized using scanning electron microscopy, transmission electron microscopy, Fourier transform infrared spectroscopy and ultraviolet-visible spectroscopy. Scanning electron microscopy is a technique that generates a high-resolution 3D image of the product providing morphological and compositional information [9,31]. It allowed us to observe clusters of multi-walled carbon nanotubes (MWCNTs) with amorphous carbon particles attached to the surface of the nanotubes. Transmission electron microscopy is a technique that reveals the internal structure of the nanotubes [32]. It corroborated outer and inner diameters of $24 \mathrm{~nm}$ and $5 \mathrm{~nm}$, respectively, and an interlayer distance of $0.4 \mathrm{~nm}$. The bands at $\tilde{v} 1550$ and $1200 \mathrm{~cm}^{-1}$ in the FT-IR spectra is attributed to the $\mathrm{C}=\mathrm{C}$ bonds within the CNTs structure. The electromagnetic absorbance using UV-Vis spectroscopy identified peaks at 204 and $256 \mathrm{~nm}$ corresponding to the $\mathrm{sp}^{2}$ hybridized carbon atoms within the CNTs. 


\section{Experimental}

\section{Experimental device}

The CNT synthesis system makes use of the arc discharge method and is shown in Fig. 1. A cylindrical reactor of $100 \mathrm{~mm}$ diameter was implemented employing a glass tube-like chamber, sealed at both extremes with polyamide covers. A stainless-steel electrode-holder, an Ar gas inlet valve, and a pressure sensor coupling were attached to the top cover. A mobile electrode-holder and a vacuum pump coupling were installed on the bottom cover [33]. The upper electrode-holder supported a $7 \mathrm{~mm}$ diameter graphite rod as the cathode, and the lower electrode-holder supported a $9 \mathrm{~mm}$ diameter graphite rod serving as the anode. A $3 \mathrm{~mm}$ wide and $3 \mathrm{~mm}$ deep hole was drilled into the tip of the anode and was filled with either $\mathrm{Ni}$ or a $\mathrm{Ni} / \mathrm{Y}$ mixture serving as catalysts.

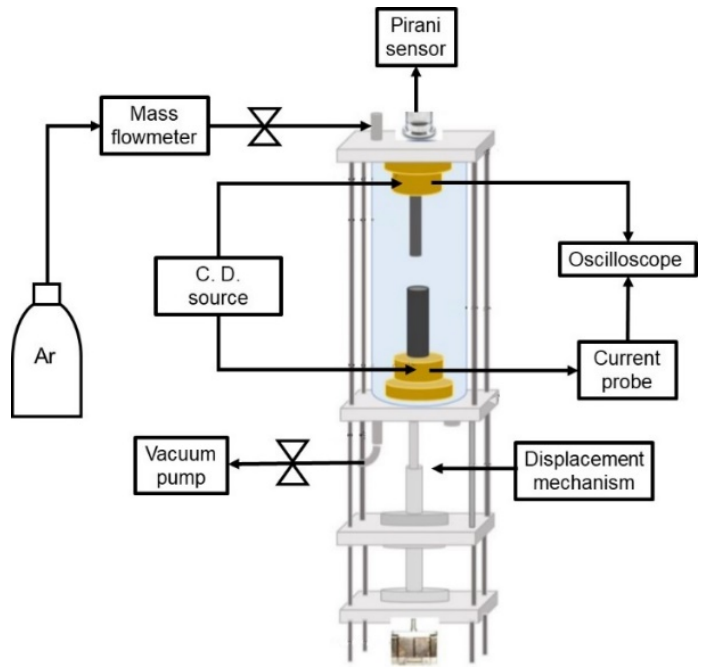

Fig. 1. The system for CNTs synthesis by arc discharge used in this work.

The CNTs synthesis was studied with and without the use of catalysts. Ni (99.99 \%) and Y (99.5\%) were purchased from Aldrich-Sigma. As catalyst, $5 \%$ wt. Ni was mixed with $95 \%$ wt. graphite powder. Also, $2 \%$ wt. Ni and $4 \%$ wt. Y were mixed with $94 \%$ wt. graphite. Both $\mathrm{Ni}$ and $\mathrm{Ni} / \mathrm{Y}$ were grinded with an agate mortar and sieved with a mesh of $75 \mu \mathrm{m}$. CNTs synthesis was performed in an inert atmosphere introducing an Ar flow of $1.43 \mathrm{~cm}^{3} / \mathrm{min}$ monitored by FMA1700A mass flowmeter, applying a pressure of $39 \mathrm{kPa}$ generated by Adixen Pascal 2005 SD vacuum pump and measured with an MKS Pirani $901 \mathrm{P}$ pressure sensor. These conditions allow generating a stable plasma within the chamber [33].

\section{CNTs synthesis by arc discharge}

The arc discharge was generated by using a DC power supply and biasing both electrodes at an average voltage of 32.5 V monitored by Tektronix TBS-1102B-EDU oscilloscope. A peak current of 99 A was applied measured by Tektronix PG0 15 A current probe [33]. The arc discharge was ignited and controlled by keeping a gap distance of $1 \mathrm{~mm}$ between the two electrodes, which was controlled by anode movement using a vertical displacement mechanism consisting of an endless shaft coupled to a NEMA 23 stepper motor that is connected to an Arduino ${ }^{\circ} \mathrm{UNO}$ microcontroller. CNTs were collected after arc discharge formation following chemical treatment with $\mathrm{HCl}$ solution at $1 \mathrm{M}$ (Golden Bell $38 \%$ ) to remove metallic impurities from remaining catalysts. Subsequently, CNTs were sonicated in a Cole-Parmer ultrasonic bath for 60 minutes to disperse amorphous carbon clusters; then, CNTs were decanted and washed with deionized water. Finally, the CNTs were dried at $70{ }^{\circ} \mathrm{C}$ in a Thermolyne furnace for 24 hours. 


\section{Characterization}

Morphology was determined by the JEOL JSM-6610LV scanning electron microscope (SEM). The CNTs samples were coated with gold and supported on a carbon adhesive tape. Moreover, the elemental composition was obtained employing an X-ray energy dispersion spectrometer (EDS) at a working voltage of $20 \mathrm{kV}$. Also, the morphology of CNTs was obtained by the JEM 2010HT transmission electron microscope (TEM) taking a drop of CNTs diluted in isopropyl alcohol supported on a 2-mm diameter copper grid. Functional groups of CNTs were identified using a Varian 640-IR spectrophotometer in the range from $\tilde{v} 4000$ to $500 \mathrm{~cm}^{-1}$ applying 180 scans. Likewise, electromagnetic absorbance was determined using a Thermo Scientific model Evolution Array UV-Vis spectrophotometer in the range from 190 to $780 \mathrm{~nm}$ employing isopropyl alcohol (Aldrich ACS $99.5 \%$ ) as a dispersive medium.

\section{Results and discussion}

\section{CNTs synthesis}

Fig. 2(a) shows the electrical signals measured between the polarized electrodes before arc discharge ignition with an average voltage of $33.5 \mathrm{~V}$ and an average current of $92.5 \mathrm{~A}$. Both electrical waveforms were in phase. During the arc discharge generation (Fig. 2(b)), the electrical waveforms presented an average voltage of $30 \mathrm{~V}$ and an average current of $75 \mathrm{~A}$ with a peak current of $95 \mathrm{~A}$. During the arc discharge, the demanded electric power was calculated at $2.25 \mathrm{~kW}$ by multiplying the average voltage and the average current.

a)

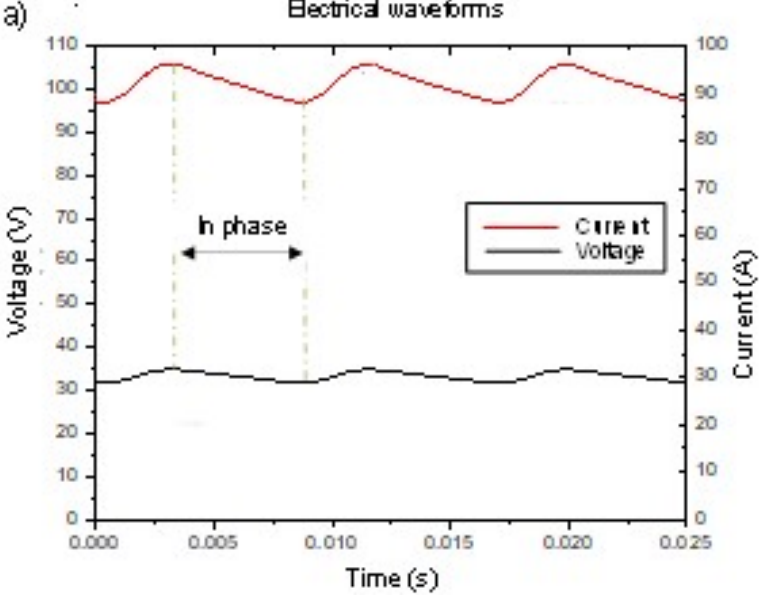

Bectrical wavetoms

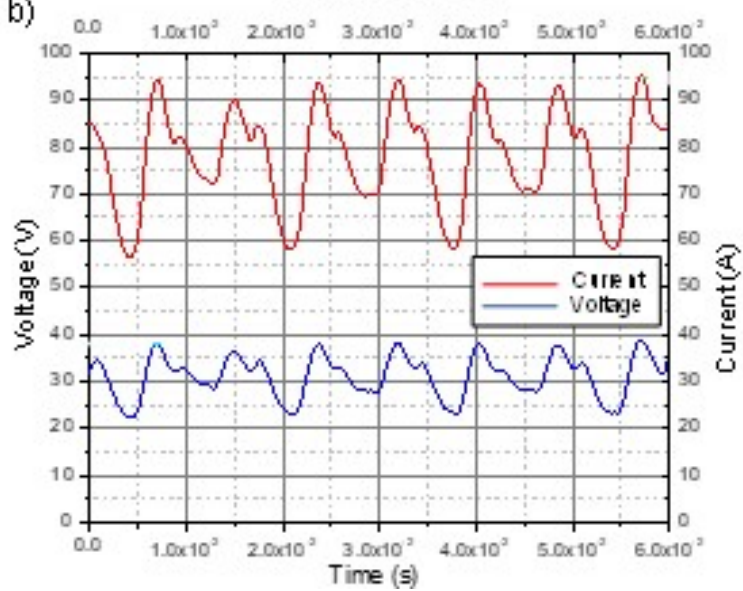

Fig. 2. Voltage and current waveform (a) before arc discharge, (b) during arc discharge.

The arc discharge formation during CNTs synthesis is shown in Fig. 3(a). After the arc discharge formation, the cylindrical reactor presented carbon powder deposits inside the chamber and both electrodes. The appearance of a collar on the anode was also observed (Fig. 3(b)) [16]. These deposits were due to the intensive vaporization that arc discharge submits to each electrode. Carbon powder (Fig. 3(c)) collected from the reactor presented a refined appearance [34] due to the carbon sublimation-deposition process. 
a)

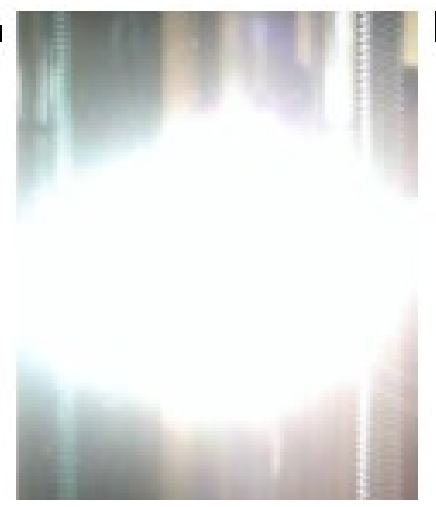

b)

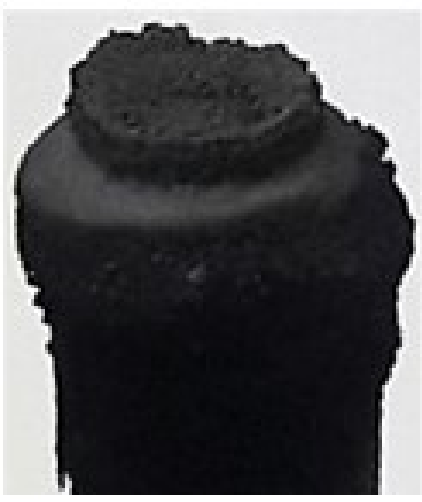

c)

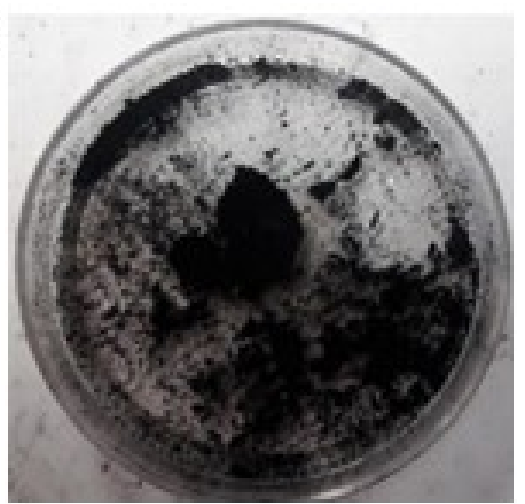

Fig. 3. CNTs synthesis (a) arc discharge formation, (b) collar on anode, (c) carbon powder collected.

\section{Study of the Morphology of CNTs using SEM and TEM}

Graphite was vaporized without catalysts, and in the presence of Ni and a Ni/Y mixture applying the arc discharge method following chemical treatment with $\mathrm{HCl}$ at $1 \mathrm{M}$. The SEM micrographs of carbon powder synthesized without catalysts (Fig. 4(a)) revealed a morphology based on carbon nanoparticle clusters. Likewise, the morphology of carbon powder synthesized in the presence of $5 \% \mathrm{wt}$. Ni (Fig. 4(b)) presented elongated and straight nanotubes attached to amorphous carbon particles. In contrast, the morphology of carbon powder synthesized in the presence of $2 \% \mathrm{Ni} / 4 \% \mathrm{Y}$ wt. (Fig. 4(c)) exhibited shortened and curved nanotubes adhered to amorphous carbon particles. The morphology observed in both samples of carbon powder synthesized in the presence of metallic catalysts presented the typical feature of nanotubes produced applying the arc discharge method $[16,34]$.

a)

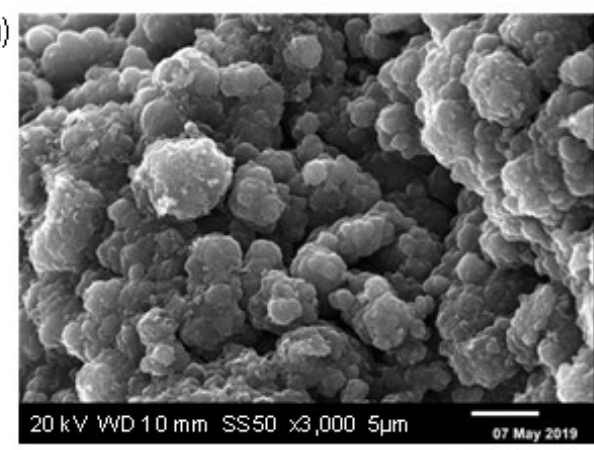

c)

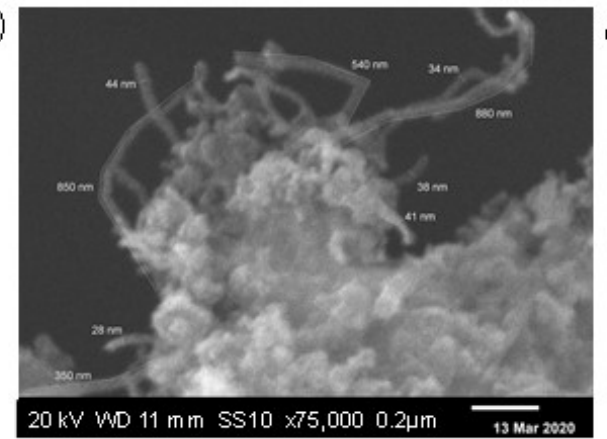

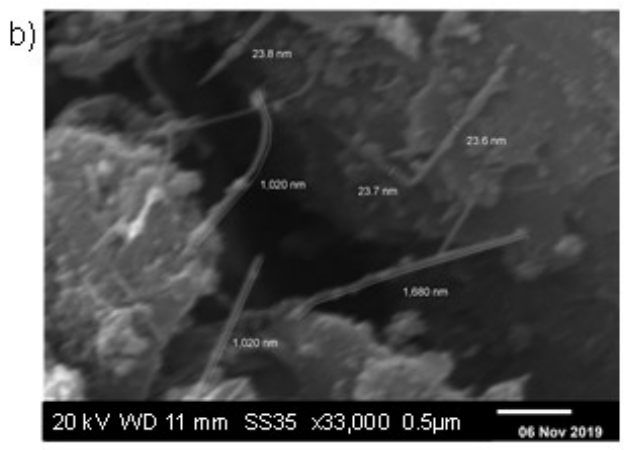

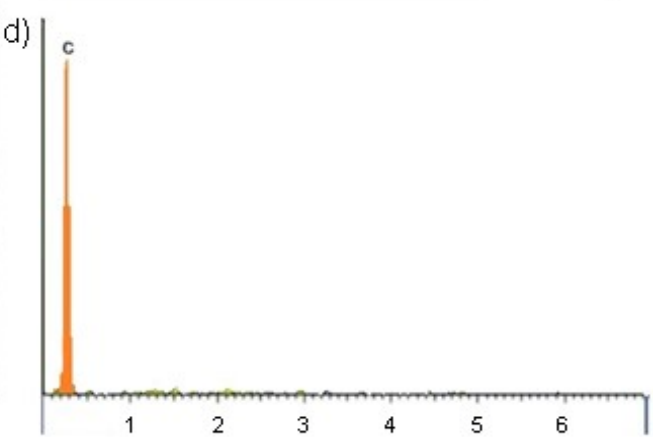

Fig. 4. SEM determined morphology of CNTs obtained (a) without catalysts, (b) $5 \% \mathrm{wt}$. Ni, (c) $2 \% \mathrm{Ni} / 4 \% \mathrm{Y}$ wt., (d) Elemental composition with $2 \% \mathrm{Ni} / 4 \% \mathrm{Y}$ wt. by EDS. 
In the morphology of CNTs synthesized with Ni (Fig. 4(b)), an average outer diameter of $24 \mathrm{~nm}$ and variable lengths from 690 to $1680 \mathrm{~nm}$ were identified. Similarly, in the morphology of CNTs synthesized with a $2 \% \mathrm{Ni} / 4 \%$ Y wt. mixture (Fig. 4(c)) an outer average diameter of $34 \mathrm{~nm}$ and variable lengths from 350 to $880 \mathrm{~nm}$ were identified. Similar measurements of CNTs were reported in the other works [35-37]. EDS analysis was applied at CNTs synthesized with a $2 \% \mathrm{Ni} / 4 \% \mathrm{Y}$ mixture because it increased nanotube production. The EDS spectrum of CNTs (Fig. 4(d)) indicated a peak at $0.3 \mathrm{keV}$, which pointed out that the elemental composition was $100 \%$ carbon observing the absence of metallic impurities. Likewise, the lack of $\mathrm{Cl}$ was observed due to the washing of the carbon powder with deionized water. Nevertheless, the presence of $\mathrm{H}$ cannot be determined by means of EDS due to the limitations of the technique.

The morphology obtained using the TEM technique (Fig. 5(a-c)) of the CNTs synthesized in the presence of a $2 \% \mathrm{Ni} / 4 \% \mathrm{Y}$ wt. mixture revealed that the CNTs have a great number of layers and are therefore properly described as multiple-wall carbon nanotubes (MWCNTs) with amorphous carbon particles attached to the surface of the nanotubes; this morphology was previously observed in other works [9,38]. Carbon nanoparticles confined inside CNTs by the effect of the arc discharge were also detected and informed previously in other work [38]. The measurement of outer and inner diameters and interlayers distance of MWCNTs was realized (Fig 5(a-c)). A MWCNTs cluster presented an average outer diameter of $24.6 \mathrm{~nm}$. Also, in two nanotubes next to an amorphous carbon particle (Fig. 5(b), the average outer diameter was 23.24 $\mathrm{nm}$. Moreover, in two nanotubes with some amorphous carbon particles adhered to one of them (Fig. 5(c)), the average outer diameter was $19 \mathrm{~nm}$. Meanwhile, the average inner diameter of $5 \mathrm{~nm}$ was measured for MWCNTs on different section-samples (Fig. 5(a-d)). The outer and inner diameters of the MWCNTs were like the reported in some other studies [38-40]. The average interlayer distance in the MWCNTs (Fig. 5(d)) was 0.4 $\mathrm{nm}$, that is similar to values reported in other studies [35,40]. Finally, the TEM and SEM derived average diameter of the MWCNTs were in the nanometric scale.

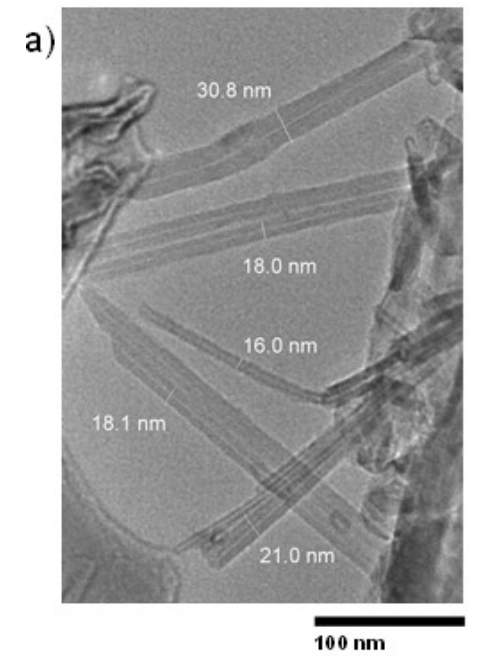

c)

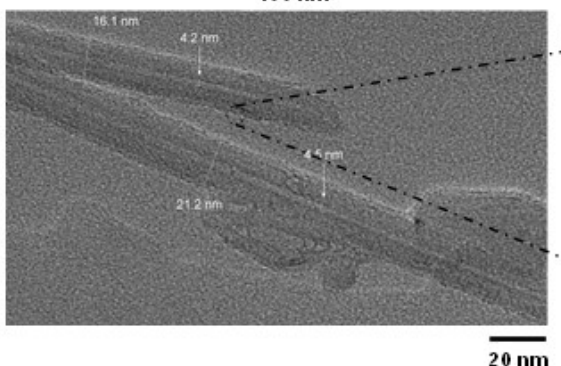

b)
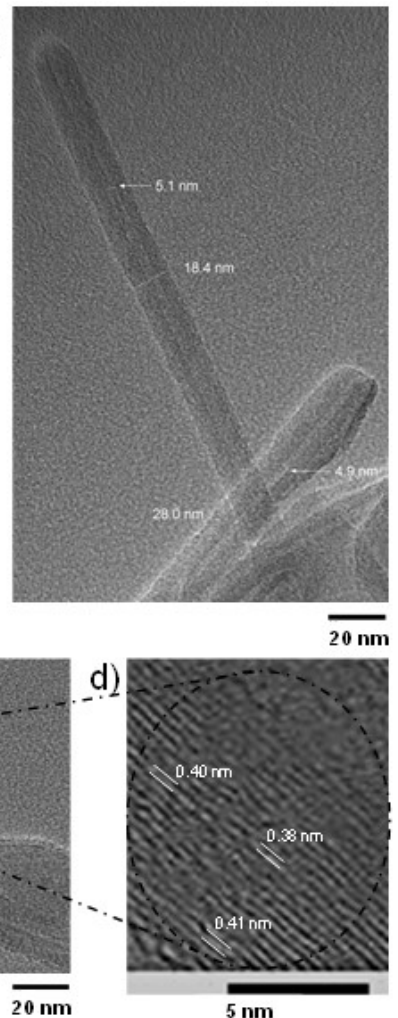

Fig. 5. Morphology of the MWCNTs obtained through TEM, (a-c) outer and inner diameters, (d) interlayers distance. 


\section{FT-IR spectroscopy}

Functional groups identification utilizing FT-IR spectroscopy, without-vaporized graphite powder and MWCNTs powder produced by arc discharge method in the presence of a $2 \% \mathrm{Ni} / 4 \% \mathrm{Y}$ wt. mixture following chemical treatment with $\mathrm{HCl}$ at $1 \mathrm{M}$, are shown in Fig. 6. There are no significant absorption bands in the spectrum of the without-catalyst vaporized graphite [41]. Meanwhile, in the MWCNTs spectrum some functional groups adhered to the structure of MWCNTs were identified; some peaks were located at $\tilde{v} 3700$ and $3300 \mathrm{~cm}^{-1}$ and were related to the stretching $\mathrm{O}-\mathrm{H}$ bond vibration generated by adsorbed atmospheric humidity [40, 41]. Also, bands located at $\tilde{v} 2850$ and $2800 \mathrm{~cm}^{-1}$ were related to the vibration of the $\mathrm{C}-\mathrm{H}$ bonds that are present due to the formation of $\mathrm{CH}_{\mathrm{x}}$ groups on the surface of the MWCNTs during the synthesis and chemical treatment with $\mathrm{HCl}$ at $1 \mathrm{M}[40,41]$. Another peak was detected at $\tilde{v} 1550 \mathrm{~cm}^{-1}$ that corresponded to the $\mathrm{C}=\mathrm{C}$ bond vibrations and belongs to the hexagonal CNTs structure [40, 41]. The band at $\tilde{v} 1200 \mathrm{~cm}^{-1}$ corresponds to the $\mathrm{C}=\mathrm{C}$ bonds originated from the $\mathrm{sp}^{2}$ hybridized carbon atoms in the disordered regions of CNTs [41]. The band at $\tilde{v} 1050 \mathrm{~cm}^{-1}$ corresponds to the $\mathrm{C}-\mathrm{O}$ bond vibrations exhibited slight oxidation of the MWCNTs due to chemical treatment with $\mathrm{HCl}$ at $1 \mathrm{M}$ [41].

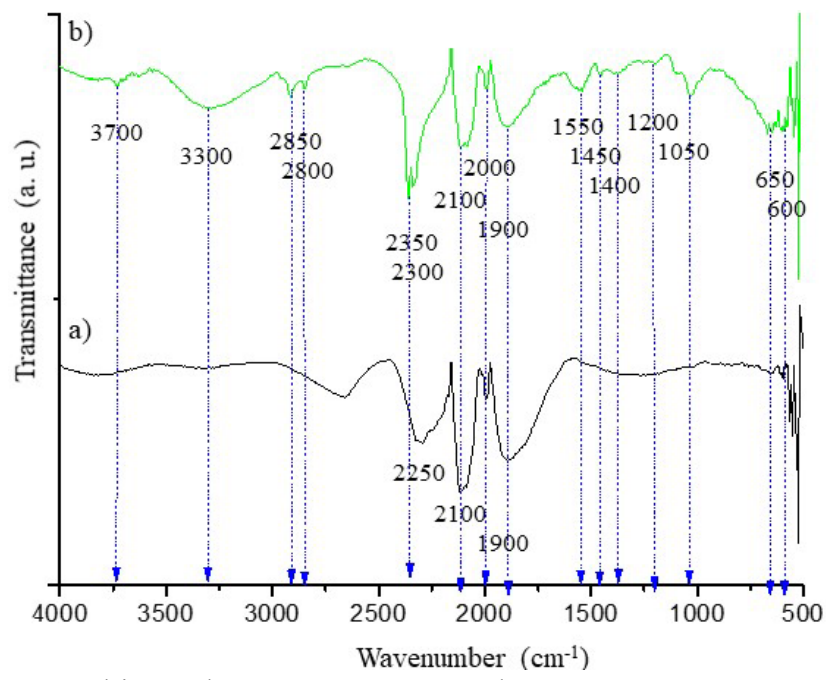

Fig. 6. FT-IR spectra of (a) graphite and (b) MWCNTs powder.

\section{UV-Vis spectroscopy}

UV-Vis electromagnetic absorbance of MWCNTs produced by the arc discharge method following chemical treatment with $\mathrm{HCl}$ at $1 \mathrm{M}$ is presented in Fig. 7. The UV-Vis spectrum of MWCNTs shows two absorbance bands at 204 and $256 \mathrm{~nm}$ corresponding to sp ${ }^{2}$ hybridization, inside the range from 310 to $155 \mathrm{~nm}$ associated with the $\pi$ plasmon [42]. The $\mathrm{sp}^{2}$ hybridization was identified with the typical $\pi-\pi^{*}$ electron transitions in the SWCNTs and MWCNTs [43]. Moreover, the absorbance band at $256 \mathrm{~nm}$, located inside the range from 253 to $260 \mathrm{~nm}$ corresponds to the characteristic absorbance band of MWCNTs [44, 45]. Another absorbance band was located at $562 \mathrm{~nm}$ inside the range from 440 to $645 \mathrm{~nm}$, which indicates transitions of metallic CNTs [42]. After this absorbance band, the spectrum of CNTs remains practically constant. 
Fig. 7. UV-Vis spectrum of MWCNTs.

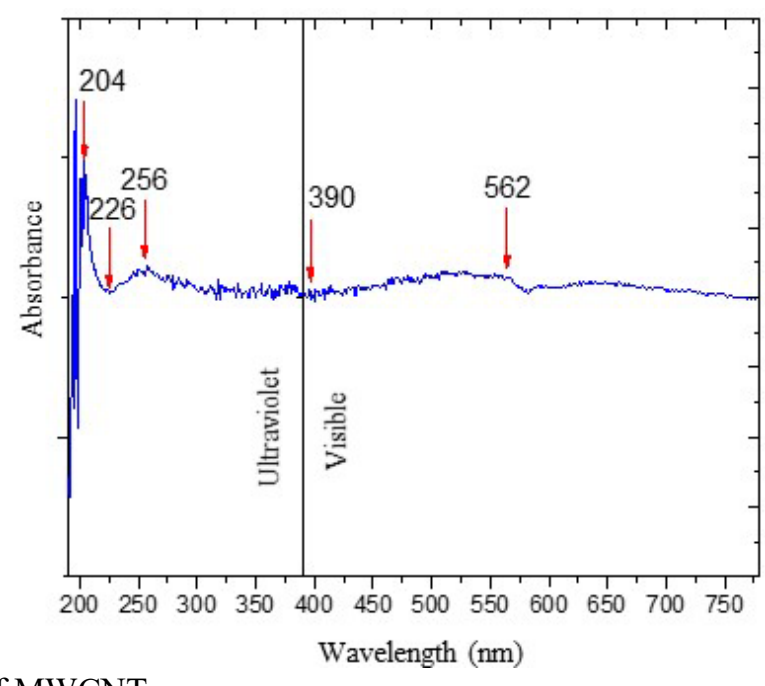

\section{Conclusion}

MWCNTs were obtained by the arc discharge method by applying an average voltage of $30 \mathrm{~V}$ and a peak current of $95 \mathrm{~A}$, which required an electrical power of $2.25 \mathrm{~kW}$. The glass chamber of the reactor allowed observing the process of synthesis during the arc discharge and the carbon powder deposits at the end of the discharge. The morphology observed by the SEM technique showed elongated and straight MWCNTs with Ni and shortened and curved MWCNTs with a $2 \% \mathrm{Ni} / 4 \% \mathrm{Y}$ wt. mixture. All MWCNTs were detached from amorphous carbon particles. The yield of MWCNTs significantly increased employing metal catalysts such as $\mathrm{Ni}$ and $\mathrm{Ni} / \mathrm{Y}$ mixture at a pressure of $39 \mathrm{kPa}$ under an atmosphere of Ar. The morphology determined by the TEM technique showed MWCNTs with similar diameter measurements obtained by SEM. The results of EDS spectra revealed that the MWCNTs synthesized after chemical treatment with $\mathrm{HCl}$ at $1 \mathrm{M}$ had low impurity contents.

The functional groups detected by FT-IR spectroscopy presented some bands characteristic for MWCNTs. Besides, the FT-IR spectra verified the functionalization of the nanotubes with different functional group. The binding of these groups to the surface of MWCNTs may tune the properties of the nanotubes and enable diversified applications of CNTs, such as in the development of energy storage and conversion devices. $\mathrm{UV}-\mathrm{V}$ is electromagnetic absorbance exhibited the properties of $\mathrm{sp}^{2}$ hybridization related to the $\pi-\pi^{*}$ transitions in the MWCNTs. Due to this nature, MWCNTs synthesized with the arc discharge method employing metal catalysts could form composites with conducting polymers used in developing of OPCs as working electrodes.

\section{Acknowledgements}

Arturo Tepale Cortés is thankful to the National Council of Science and Technology (CONACyT) for his scholarship (grant No. 483853). The authors are grateful to the Environment Engineering Research Laboratory of the Toluca Technological Institute (LIIA-ITT) and the Plasma Applications Laboratory of the Nuclear Research National Institute (LAP-ININ) for their technical assistance. 


\section{References}

1. Zou, J.; Zhang, Q. In Carbon Nanotubes and Their Applications, Ed. CRC Press. USA. 2012, 1-27.

2. Eatemadi, A.; Daraee, H.; Karimkhanloo. H.; Kouh, M.; Zarghami, N.; Akbarzadeh, A.; Abasi, M.; Hanifehpou, Y.; Joo, S. W. Nanoscale Res. Lett. 2014, 9, 1-31. DOI: http://doi:10.1186/1556-276X-9393.

3. Candelaria, S. L.; Shao, Y.; Zhou, W.; Li, X.; Xiao, J.; Zhang, J.-G.; Wang, Y.; Liu, J.; Li, J.; Cao, G. Nano Energy. 2012, 1, 195-220. DOI: http://doi:10.1016/j.nanoen.2011.11.006

4. Chen, T.; Dai, L. Mater. Today. 2013, 16, 272-280. http://dx.doi.org/10.1016/j.mattod.2013.07.002

5. Hanaei, H,; Assadi, M. K.; Saidur, R. Renewable Sustainable Energy Rev, 2016, 59, 620-635 DOI: http://dx.doi.org/10.1016/j.rser.2016.01.017

6. Paradise, M.; Goswami, T. Mater. Des. 2007, 28, 1477-1489. DOI: http://doi:10.1016/j.matdes.2006.03.008

7. Liu, J.; Dai, L. Carbon Nanomater. Adv. Energy Syst., Ed. John Wiley \& Sons, Inc. USA. 2015. $165-$ 189.

8. Zhang, L. L.; Zhao, X. S. Chem. Soc. Rev. 2009, 38, 2520-2531. DOI: http://DOI:10.1039/b813846j

9. Sharma, R.; Sharma, A. K.; Sharma, V. Cogent Engineering. 2015, 2, 1-10. DOI: http://dx.doi.org/10.1080/23311916.2015.1094017

10. He, B.; Tang, Q.; Luo, J.; Li, Q.; Chen, X.; Cai, H. J. Power Sources. 2014, 170-177. DOI: http://dx.doi.org/10.1016/j.jpowsour.2014.01.072

11. Snook, G. A.; Kao, P.; Best, A. S. J. Power Sources. 2011, 196, 1-12. DOI: http://doi:10.1016/j.jpowsour.2010.06.084

12. Hosseini, T. ; Kouklin, N. In Carbon Nanotubes: Curr. Prog. Their Polym. Compos., Ed. InTech, Croatia. 2016, 95-123. DOI: http://dx.doi.org/10.5772/62692

13. Dai, H. Acc. Chem. Res. 2002, 35, 1035-1044.

14. Ostrogorsky, A. G.; Marín, C. Heat Mass Transfer. 2006, 42, 470-477. DOI: http://DOI:10.1007/s00231-005-0644-7

15. Levchenko, I.; Keidar, M.; Xu, S. Kersten, H.; Ostrikov, K. J. Vac. Sci. Technol., B: Microelectron. Nanometer Struct.-Process. Meas. Phenom. 2013, 31, 1-16. DOI: http://dx.doi.org/10.1116/1.4821635

16. Mohammad, M. I.; Moosa, A. A.; Potgieter, J. H.; Ismael, M. K. ISRN Nanomater. 2013, 1-7. DOI: http://dx.doi.org/10.1155/2013/785160

17. Tarasov, B. P.; Muradyan, V. E.; Shul'ga, Y. M.; Krinichnaya, E. P.; Kuyunko, N. S.; Efimov, O. N.; Obraztsova, E. D.; Schur, D. V.; Maehlen, J. P.; Yartys, V. A.; Lai H.-J. Carbon. 2003, 41, 13571364.

18. Mamun, A. A.; Ahmed, Y. M.; Muyibi, S. A.; Al-Khatib, M. F. R.; Jameel, A. T.; AlSaadi M.A. Arabian J. Chem. 2016, 9, 532-536. DOI: http://dx.doi.org/10.1016/j.arabjc.2013.09.001

19. Hou, P.-X.; Liu C.; Cheng H.-M. Carbon. 2008, 46, 2003-2025. DOI: http://doi:10.1016/j.carbon.2008.09.009

20. Wen, L.; Jong-Beom, B.; Liming, D. In Carbon Nanomater. Adv. Energy Syst., Ed. John Wiley \& Sons, Inc. USA. 2015, XVII-XVIII.

21. Lian, Y.; Maeda, V.; Wakahara, V.; Akasaka, T.; Kazaoui, V.; Minami, V.; Shimizu, V.; Choi, V.; Tokumoto, V. J. Phys. Chem. B. 2004, 108, 8848-8854.

22. Prasek, J.; Drbohlavova, J.; Chomoucka, J.; Hubalek, J.; Jasek, O.; Adam, V.; Kizek, R. J. Mater. Chem. 2011, 21, 15872-15884. DOI: $10.1039 / \mathrm{c} 1 \mathrm{jm} 12254 \mathrm{a}$ 
23. Prakash, D.; Amente, C.; Dharamvir. K.; Singh, B.; Singh, R.; Shaaban, E. R.; Al-Douri, Y.; Khenata, R.; Darroudi, M.; Verma, K.D. Ceram. Int. 2016, 42, 5600-5606. DOI: http://dx.doi.org/10.1016/j.ceramint.2015.11.074

24. Zhang, J.; Wu, C.; Hou, K.; Huang, M.; Guan, L. Int. J. Hydrogen Energy, 2018, 43 , 15687- 5692. DOI: https://doi.org/10.1016/j.ijhydene.2018.07.048

25. Pifferi, V.; Cappelletti, G.; Di Bari C.; Meroni, D.; Spadavecchia, F.; Falciola, L. Electrochim. Acta, 2014, 146, 403-410. DOI: http://dx.doi.org/10.1016/j.electacta.2014.09.099

26. Das, R.; Ali, M. E.; Hamid, S. B. A. J. Nanomater. 2014, 2014, 1-9. DOI: http://dx.doi.org/10.1155/2014/945172

27. Wulan, P. P. D. K.; Permana, G.; Putri, W. A. AIP Conf. Proc. 2020, 2255, 0600141-0600146. DOI : https://doi.org/10.1063/5.0014074

28. Raniszewski, G.; Wiak, S. , Pietrzak, L.; Szymanski, L.; Kolacinski, Z. Nanomaterials. 2017, 7, 1-12. DOI: doi:10.3390/nano7030050

29. Roslan, M. S.; Chaudhary, K. T.; Doylend, N. J. Saudi Chem. Soc. 2019, 23, 171-181. DOI: https://doi.org/10.1016/j.jscs.2018.06.003

30. Yermagambet, B. T.; Kazankapova, M. K.; Kassenova1, Z. M.; Nauryzbayeva, A. T. Nats Akad. Nauk. Resp. Kaz., Ser. Khim. Tekhnol. 2020, 5, 126-133. DOI : https://doi.org/10.32014/2020.2518-1491.89

31. Kannan, M., in Fundamentals and applications of Nanotechnology, Subramanian K. S.; Janavi G. J.; Marimuthu S., Ed. Astral, 2018, 81-92.

32. Brydson, R.; Brown, A.; Benning, L. G. Rev. Mineral. Geochem. 2014, 78. 219-269. DOI: https://doi.org/10.2138/rmg.2014.78.6

33. Tepale, A.; Moreno, H.; Hernandez, C. Congr. Int. en Ing. Electrónica. Mem. ELECTRO. 2019, 41, 81-85.

34. Cotul, U.; Parmak, E. D. S.; Kaykilarli, C.; Saray, O.; Colak, O.; Uzunsoy; D. Acta Phys. Pol., A. 2018, 134, 289-291. DOI: http://DOI:10.12693/APhysPolA.134.289

35. Abdel-Salam, M.; Burke, R. Arabian J. Chem. 2017, 921-927. DOI: http://dx.doi.org/10.1016/j.arabjc.2012.12.028

36. Xu, S.; Liu, J.; Li Q. Constr. Build. Mater. 2015, 76, 16-23. DOI: http://dx.doi.org/10.1016/j.conbuildmat.2014.11.049

37. Feng, L.; Li, K-Z.; Xue, B. Mater. Lett. 2017, 187, 158-161. DOI: http://dx.doi.org/10.1016/j.matlet.2016.10.067

38. Toma, S.; Asaka, K.; Irita, M.; Saito, Y. Surf. Interface Anal. 2019, 131-135. DOI: http://DOI:10.1002/sia.6590

39. Kumar, S.; Nehra, M.; Kedia, Prog. Energy Combust. Sci. 2017, 1-35. DOI: http://dx.doi.org/10.1016/j.pecs.2017.10.005 0360-1285/

40. García-Ruiz, D. L.; Granados-Martínez, F. G.; Gutiérrez-García, C. J.; Ambriz-Torres, J.M.; Contreras-Navarrete, J.J.; Flores-Ramírez, N.; García-González, L.; Zamora-Peredo, L.; MondragónSánchez, M. L.; Domratcheva-Lvova L. Rev. Mex. Ing. Quim. 2019, 18, 659-671. DOI: https://doi.org/10.24275/uam/izt/dcbi/revmexingquim/2019v18n2/GarciaR

41. Țucureanu, V.; Matei, A.; Avram, A. M. Crit. Rev. Anal. Chem. 2016, 46, 1547-6510. DOI: http://dx.doi.org/10.1080/10408347.2016.1157013

42. Rance, G. A.; Marsh, D. H.; Nicholas, R. J.; Khlobystov , A. N. Chem. Phys. Lett. 2010, 493, 19-23. DOI: doi:10.1016/j.cplett.2010.05.012

43. Grossiord, N.; Regev, O.; Loos, J.; Meuldijk, J.; Koning, C. E. Anal. Chem. 2005, 77, 5135-5139.

44. Alafogianni, P.; Dassios, K.; Farmaki, S.; Antiohos, S. K.; Matikas, T. E.; Barkoula, N.-M. Colloids Surf., A. 2016, 495, 118-124. DOI: http://dx.doi.org/10.1016/j.colsurfa.2016.01.053 
45. Njuguna, J.; Vanli, O. A.; Liang, R. J. Spectrosc. 2015, 1-11. DOI: http://dx.doi.org/10.1155/2015/463156 